\title{
Integration of Acculturation Values of Masjid Sulaiman Banyumas in History Learning
}

\author{
Suci Rahayu, ${ }^{1}$ Sariyatun ${ }^{1}$, Leo Agung Sutimin ${ }^{1}$ \\ ${ }^{1}$ Postgraduate Program of History Education Postgraduate Program of Sebelas \\ Maret University \\ E-mail: rahayusuci81@yahoo.com
}

\begin{abstract}
The Great Mosque of Nur Sulaiman is one of the historical sites in Banyumas, built in 1755 by the Regent of Banyumas, R.T. Yudonegoro III. This research elucidates indigenous values of Nur Sulaiman Great Mosque. The indigenous values of the architecture were analyzed with literature study involved collecting sources, literature, archives, books, scientific journals to strengthen the theoretical review related to the indigenous values of the Great Mosque of Banyumas. The finding of research showed that among other mosques, the architecture of Grand Mosque of Nur Sulaiman Banyumas has uniqueness because it contains the elements of the indigenous culture of Indonesia, Hindu-Buddhism, and Islam. It means that the mosque has an acculturation values. The authors found the acculturation values of the great Mosque of Nur Sulaiman, encompassing: (1) religiosity, (2) tolerance, (3) cooperation, and (4) creativity. Based on the finding, the authors conclude that this historical site could be used as a source to develop the model of learning history. The implication of the research drives the authors and another researcher to expand the discussion in the integration of indigenous values of the great mosque in learning history. Thus, the role of learning history in providing knowledge on our local wisdom is becoming very necessary and useful for learners.
\end{abstract}

\section{Keywords: indigenous values, Mosque Nur Sulaiman, Learning History}

\section{INTRODUCTION}

The Law of Indonesian National Education System number 20 of 2003 article 1 paragraph 1 mentions that education is a conscious and planned effort to create an atmosphere of learning process so that learners actively develop their potential with spiritual, religious, self-control, personality, intelligence, noble character needed by himself, society, nation, and state. In line with the Indonesian National Education System, according to Carter V. Wiji Suwarno (2006: 20) stated that education consists of two important meanings. First, education could be defined as the whole process whereby a person develops other positive values, attitudes and behavioral forms in the community in his place of life. Second, education is the social process by which people are exposed to a selected and controlled environmental influence (especially in 
school) so that the person can gain or experience the development of social ability and individual ability optimally. Sudjana (2004: 35) support the definition with argumentation that education is a human interaction between educators or teachers with learners that can support the development of human in whole oriented to values and the preservation and development of cultures associated with human development effort. Based on the definitions above, it can be concluded that education is an interaction between teachers with learners that can support the development of human in whole oriented to values and the preservation and development of cultures associated with human development efforts.

Meanwhile, according to Law no. 20, 2003 article 1 paragraph 2, National education is an education based on Pancasila as the state constitution of the Republic of Indonesia. Pancasila is the national ideology based on religion, a national culture of Indonesia, and the demands of world change. On the subject of Pancasila, education has an important role in preparing the next generation of intelligent people as well as noble personality to be able to live in society. Education also means the efforts to prepare young people to be able to adapt and compete in the competition and the challenges of globalization era. Education put forward the spiritual aspect, noble character, and personality. The function and objectives of national education are set forth in Law no. 20 of 2003 article 3. The function of National education is to develop ability and form national prestigious character and civilizations in order to educate nation life for students' potential development to be the religious humans with the faith and piety to the Almighty; they are supposed to be noble, knowledgeable, skillful, creative, autonomous, democratic, and responsible Indonesian Citizens (Munib, 2011: 142). The growing potential of learners is the result of the learning process organized by the school. The learning environment and the learning process are well designed, so the students could develop their ability and skill. The education should be oriented toward the student active learning; they should be seen as a person who develops and potential. The task of the teachers to grow and develop the students' potential will eventually adapt and live their life in globalization era. To answer such challenges, it needs some breakthroughs in addressing education issues.

One of the lessons learned in the educational unit is learning history. Through learning the history, learners are invited to examine the linkage of life experienced by themselves, society and nation. The students grow into young peoples who have the attitude of historical awareness, get inspiration or wisdom from the stories of heroes, as well as a national tragedy, which in turn encourages the formation of their way of thinking, namely rational, critical, and empirical. It means that learning history could develop an attitude of appreciating human values (Wiyanarti, 2012: 2). According to Bourdillon (1994), learning objectives of learning history ideally help learners achieve the following abilities: (1) understand the past in contemporary contexts; (2) arouse interest in a meaningful past; (3) help understand the identity; (4) help understand cultural roots and interrelations with various aspects of real life; (5) provide knowledge and comprehension of the state and culture of other 
nations in different parts of the world; (6) create the students inquiry and solve problems; and (7) introducing the pattern of scientific thinking.

The above explanation emphasizes on the definition and the function of Indonesian education that in line with the Pancasila and the main objectives of the state to educating the people. In an attempt to reach the objectives, the authors believe that the education should be supported by other elements in society. One of the elements is the local indigenous values that live in the society. The local indigenous values could be found in the historical site, manuscript or other cultural heritages.

The Great Mosque of Nur Sulaiman Banyumas is one of the historic objects that could be used as to support the learning history process. The Great Mosque of Nur Sulaiman Banyumas is located in Banyumas Regency precisely in Banyumas Town. The Great Mosque of Nur Sulaiman Banyumas is one of the historical heritage mosques built during the Regent R.T. Yudonegoro III, the 9th of Banyumas regent precisely in 1755. The name of the Great Mosque of Nur Sulaiman Banyumas was taken from a mosque architect named Nur Daiman and the leader of the mosque named Sulaiman. Then, it was combined into Nur Sulaiman. The Great Mosque of Nur Sulaiman Banyumas as one of the oldest mosques in Banyumas has cultural acculturation values such as the values of religion, tolerance, cooperation, and creativity. However, many young men are less aware of the existence and the great values of the Great Mosque Nur Sulaiman Banyumas. Therefore, the role of learning history in providing knowledge on our local wisdom is very necessary and useful for learners.

Based on these problems, these articles focus on three analysis of the great mosque Nur Sulaiman: (1) the acculturation forms of the Great Mosque of Nur Sulaiman Banyumas; (2). the indigenous values of the Great Mosque Nur Sulaiman Banyumas; (3). the role of acculturation values of the Great Mosque of Nur Sulaiman Banyumas in learning history.

\section{METHOD}

The literature study by collecting sources, literature, archives, books, scientific journals is used as the research method in order to strengthen the theoretical review related to the integration of acculturation values of the Great Mosque of Banyumas. From the results of literature studies, the literature review is as follows: (1) Acculturation of the Great Mosque of Nur Sulaiman Banyumas, (2) Acculturation values of the Great Mosque of Nur Sulaiman Banyumas, (3) The role of acculturation values of the Great Mosque of Nur Sulaiman Banyumas in History Learning.

\section{RESULT AND DISCUSSION}

According to Krober (1948: 425), cultural acculturation consists of various changes in culture due to the engagement of two cultures that cause 
increased the similarity between those two cultures. In line with Krober argumentation, Koentjaraningrat (2005: 155) emphasized the social process of the cultural acculturation. The social process occurs when groups of people with a particular culture are interacting with different foreign cultures. The elements of foreign culture are gradually accepted and processed within the culture without causing the loss of cultural characteristic itself. Furthermore, Bee in Hadi (2006: 35) specifically explained the process of cultural acculturation refers to a process of change differentiated from the process of diffusion, innovation, and invention. Acculturation is understood as a concept that can be used as an adjective to designate a condition, for example, the condition of one culture group is more acculturated than another. Another opinion about acculturation according to Sumandiyo Hadi (2005: 35) who stated that acculturation and enculturation are two things related to each other. Acculturation as a cultural change is characterized by the relationship between two mutual give and receive culture or shooter. According to him, acculturation is the encounter between two cultures. From those definitions, it can be concluded that acculturation is a mixture of two or more cultures that produces new cultures.

\section{THE ARCHITECTURE OF GREAT MOSQUE OF NUR SULAIMAN BANYUMAS}

On the subject of the Great Mosque of Nur Sulaiman Banyumas, the acculturation values could be found in the architecture of the mosque. The acculturation forms of the Great Mosque of Nur Sulaiman Banyumas can be described as follows:

Roof

Like another ancient mosque, the roof of the Great Mosque Nur Sulaiman has the form of roof overlap or Meru roof. The overlapping roof or Meru is the roof of the mosque with three, five, seven and so forth roof levels. The form of overlapping Meru exists since the 16th century until the 18th century, as result of the fusion between Islam and pre-Islamic buildings. Meru roofs identic with temple reliefs in East Java such as Surawana, Panataran, Kedaton, Jago or overlapping temples, Jawi, and temples in Bali until nowadays (Tjandrasasmita, 2009: 239). 


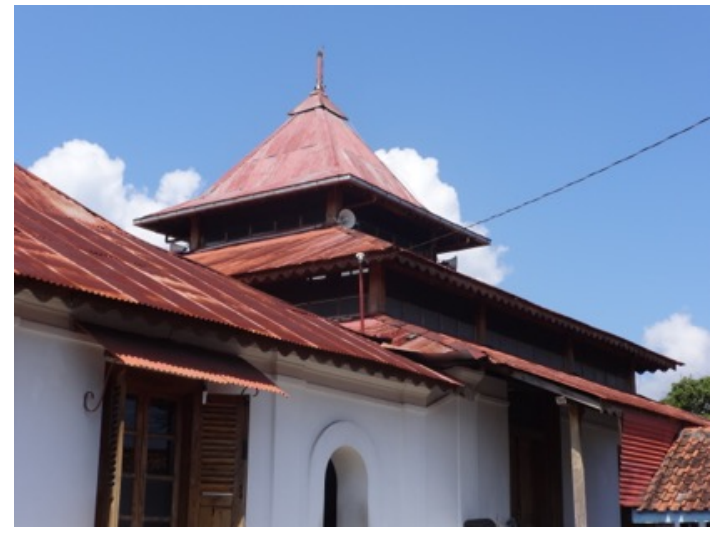

Picture 1. The Roof of Great Mosque Nur Sulaiman

This overlapping roof is a blend of local, Hindu-Buddhist and Islamic civilizations. The roof of the Great Mosque of Nur Sulaiman Banyumas on the main building is composed of three levels. The overlapping roof of three levels have their own meaning, the first stacking roof means Shari'a, the second stacking roof means tarekat, and the third stacking roof means ma'rifat (Ahmad Fanani, 2009: 129).

\section{Site plan of Building of Mosque}

The Great Mosque of Nur Sulaiman Banyumas has a square plan. The square plan is one of the hallmarks of ancient mosque buildings in Indonesia. It was the remnants of the cultural acculturation between Hindu-Buddhist, Indonesian, and Islamic cultures.

\section{The location of the mosque}

The Great Mosque of Nur Sulaiman Banyumas is located on the west side of Banyumas square. The location of the mosque is on the west side of the square reminds us of to the characteristics of the old urban design that developed the Islamic kingdoms era.

\section{Bedug}

The Great Mosque of Nur Sulaiman Banyumas is equipped with a big bedug, placed on the north side of the porch. Bedug is the original culture of the Indonesian society. In the ancient times, bedug served as a means of communication that is a sign of a call for citizens for gathered or also as a sign of danger. 


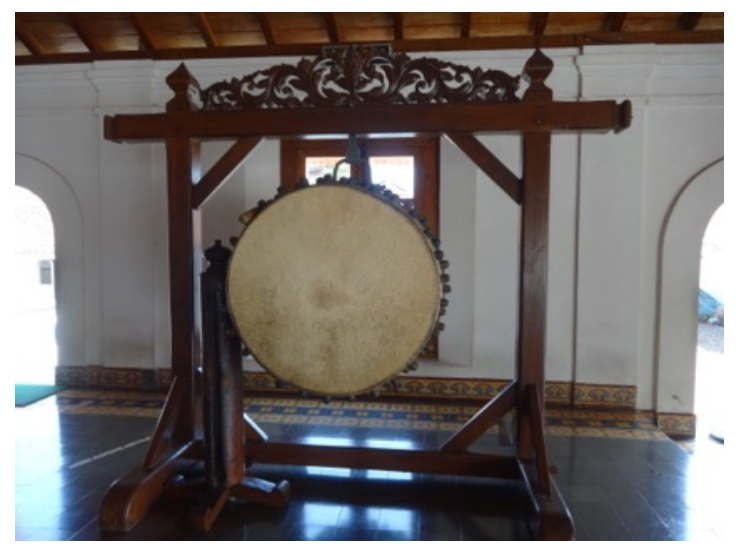

Picture 2. Bedug of Great Mosque Nur Sulaiman

Bedug is a form of Islamic acculturation with the local culture. With the entrance of Islam into Indonesia, its function is evolving as a sign prior to calling prayer or Adhan.

\section{Mihrab, pulpit, maxura}

The uniqueness of the mihrab of the Great Mosque of Nur Sulaiman Banyumas is on the own roof, which is separated from the roof of the main building of two tacked tajug, with a crown like a mace. Teak pulpit of this mosque is shaped stretcher with three staircase ornaments of golden flora.

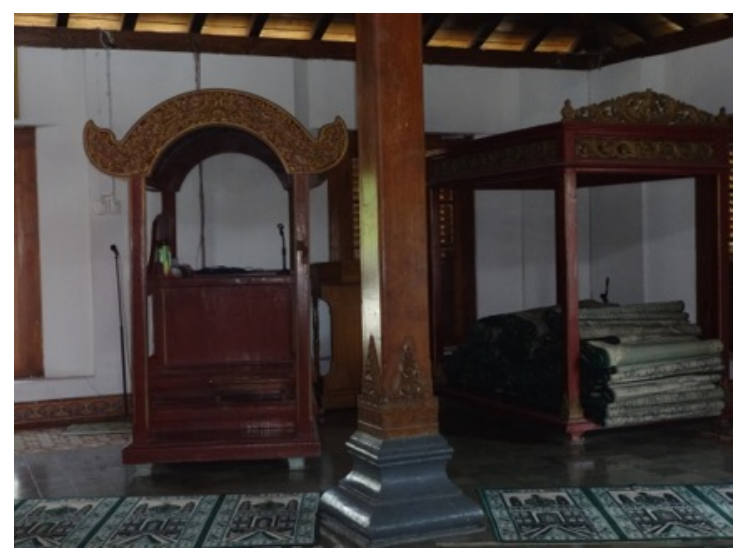

Picture 3. The Mihrab of Great Mosque Nur Sulaiman

Besides the maxura is the place of prayer used by rulers, especially when following the Friday prayers and Ied prayers. The mihrab is separate from the roof of the mosque's main hall, appears to be a prototype for mosques located in the Banyumas region.

Porch

One of the hallmarks of the ancient mosque is having a porch. The porch comes from the word "surambi", which means the rule of religious law and then the place to decide cases related to religious law in familiar with the 
porch (Juliadi, 2007: 87). The porch of Nur Sulaiman Banyumas Grand Mosque measures $11 \times 22$ meters. Beautiful wooden pillars support the porch of the mosque. There is the main door and two companion doors to enter the main room of the mosque. The third door is equipped with ornaments.

Fence

The Great Mosque of Nur Sulaiman Banyumas is equipped with a fence around the main door to the east. The railings are listed in black and white color. The meaning of the fence is to separate between the sacred and the profane life (Fanani, 2009).

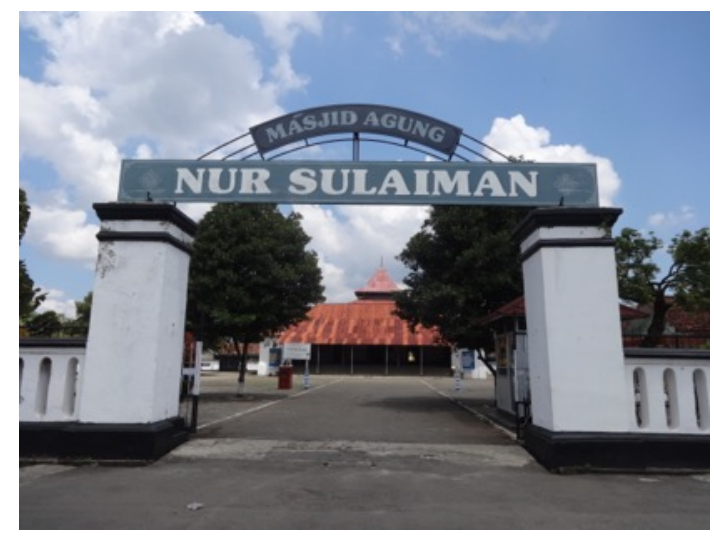

Picture 4. Fence of Great Mosque Nur Sulaiman

\section{Ornaments-carvings}

Four pillars and twelve supporting wooden pillars support the main building of the Great Mosque of Nur Sulaiman Banyumas. Ornaments on the underside of pillars are patterned and swayed with a symmetrical pattern. The printing of the pillars shows the influence of western culture on this mosque. The inner ceiling of tajug is decorated with symmetrical floral ornaments at the center and the four corners.

\section{THE ACCULTURATION VALUES OF THE GREAT MOSQUE NUR SULAIMAN BANYUMAS}

Based on the above description, the authors the indigenous local of Great Mosque Nur Sulaiman's architecture. The indigenous values could be described as follows: accepting a diversity,

Accepting a diversity

The acculturation at the Great Mosque of Nur Sulaiman Banyumas occurred for the stable society of Banyumas. In that time, the people acknowledged the diversity in society, so that it could enrich the culture of local people. 
The attitude of gotong royong (mutual cooperation)

The building of the Great Mosque of Nur Sulaiman Banyumas was done by cooperation between the people of Banyumas assisted by Kyai Nur Daiman. The construction of the mosque shows the spirit and value of cooperation.

\section{Religious Values}

The Great Mosque of Agung Nur Sulaiman Banyumas contained many religious values that interrelate with the local values of Banyumas society. There is the unity of religion elements namely Islam, Hindu, and Buddha.

\section{Respecting Each other}

Attitudes from the Banyumas community that have interacted with the other social groups or the foreigners who came to trade or other purposes have never been conflicted and welcome unless they have come to confront them. It means that they respect each other and do live in harmonious ways.

\section{Mutual Feelings}

Regardless of the diversity in Banyumas community, they must have a sense of belonging to each other and to be sure they are one and united to each other to create harmony.

Those indigenous values of The Great Mosque of Nur Sulaiman Banyumas are meaningful and relevant to the contemporary needs of society. Thus, the indigenous values should be preserved and also be transmitted for the next generations. According to Durkeim (1973), education could be used for the socializing the local values. It means that the indigenous of The Great Mosque of Nur Sulaiman Banyumas should be learned in the educational field. In the author perspectives, the learning history becomes ideal tools for the actualization of the local values.

\section{THE ROLE OF ACCULTURATION OF THE GREAT MOSQUE OF NUR SULAIMAN BANYUMAS IN THE LEARNING HISTORY}

School is a social system of society. The learners learn to interact with others, learn to understand the social norms, learn to work together, learn to appreciate, and learn various appropriate aspects of life in our society. This stems from social philosophy, that everyone needs to communicate yet they should take and give (Tirtahardja, 1994: 18). The learning process undertaken on various aspects of life and nature of this school environment will be a provision for learners to be more ready to enter the community, especially to finish education at a certain level.

The Great Mosque of Nur Sulaiman Banyumas is one of the local wisdom of Banyumas people. It is very important for the nature of Banyumas society. In an attempt to integrate the values of the Great Mosque of Nur Sulaiman 
Banyumas in everyday life, teachers should include some strategy into the learning history process. Through learning history, learners are invited to examine the linkage of life experienced by themselves, society and nation. It is affecting on the growing of the learner, which has the attitude of historical awareness, an inspiration or wisdom from the stories of heroes, as well as national tragedies that ultimately encourage the formation of the way of thinking rationally, critically, empirically, and equally. It is important to understand that history learning is able to develop an attitude of respect for human values (Wiyanarti, 2012: 2).

The indigenous values of The Great Mosque of Nur Sulaiman Banyumasare similar with 18 values that arranged by the National Education System. There are 18 values of characters such as religious, honest, tolerance, discipline, hard work, creative, independent, democratic, curiosity, the spirit of nationality, love Homeland, respect for achievement, friendship or communicative, peace loving, avid reader, caring environment, social care and responsibility. The similarity between them could be seen in the table below:

TABLE 1. THE SIMILARITY BETWEEN INDIGENOUS VALUES OF GREAT MOSQUE NUR SULAIMAN AND 18 VALUES OF CHARACTER

\begin{tabular}{|c|c|}
\hline $\begin{array}{c}\text { The indigenous values of The Great } \\
\text { Mosque Nur Sulaiman }\end{array}$ & The 18 values of character \\
\hline Accepting a diversity & Tolerance, \\
\hline $\begin{array}{l}\text { The attitude of gotong royong (mutual } \\
\text { cooperation }\end{array}$ & $\begin{array}{l}\text { Democratic, love Homeland, respect for } \\
\text { achievement, }\end{array}$ \\
\hline Religious Values & $\begin{array}{l}\text { honest, religious, caring environment } \\
\text { discipline, hard work, creative, independent, } \\
\text { curiosity, and avid reader, }\end{array}$ \\
\hline Respecting Each other & social care and responsibility, peace loving \\
\hline Mutual Feelings & $\begin{array}{l}\text { friendship or communicative spirit of } \\
\text { nationality, }\end{array}$ \\
\hline
\end{tabular}

The indigenous values of The Great Mosque of Nur Sulaiman Banyumas relate with the function of education as the process to construct and develop the character for students and sharing a sense of belonging to a local culture. This can be applied in the grand design of character education that is expected to have the character-based education. The design could be generated in form of learning media, a model of teaching, or in the form of learning material. The indigenous values of The Great Mosque support as resources for the development of media, model, and model learning. Thus, the indigenous values could be represented in the learning history process. 


\section{CONCLUSION}

Now, it the era of globalization, the demands of development in various fields becomes an absolute thing done by every nation including Indonesia. Development must be balanced between physical development and character development. Development becomes foothold as well as a strong force for the mental resilience of the Indonesian nation. In the globalization era, the young generation began to forget history, even run away from history. They prefer modernization and forget tradition, they glorify globalization but forget the locality, they animate the present but they forget and even underestimate the past. "To destroy a nation/state, then destroy the memory (history) of the young generation".

The architecture of the Grand Mosque of Nur Sulaiman Banyumas is unique among other mosques because it contains elements of the indigenous culture of Indonesia, Hindu-Buddhism, and Islam or is a form of acculturation of indigenous Indonesian, Hindu-Buddhist, and Islamic cultures.

One of the most vulnerable positives of external influences is the attitude of tolerance and togetherness. Almost most agree that tolerance is a crystallization of the nation's culture that has grown and developed in the life of Indonesian society for centuries. And no one opposes the magnitude of the benefits of developing this attitude in the lives of individuals, societies, and nations. But the current modernization that is often hastily judged as something better progressively shifts these very lofty values.

To facilitate teachers in conveying information about the historical relics in the environment of students, teachers take advantage of the historical heritage of the Great Mosque Nur Sulaiman Banyumas as a model of history learning. Heritage of the Great Mosque Nur Sulaiman Banyumas can be used in learning history so that learners recognize, understand; interpret the process of acculturation of culture and values of acculturation in Banyumas society. The implication of the research drives the authors and another researcher to expand the discussion in the integration of indigenous values of the great mosque in learning history. Thus, the role of learning history in providing knowledge on our local wisdom is becoming very necessary and useful for learners.

\section{REFERENCES}

1. Adrisijanti Romli, Inajati. 1998.Purna Pugar Masjid Agung Nur Sulaiman Banyumas. Semarang : Suaka peninggalan Sejarah Dan Purbakala Jawa Tengah

2. Aman. 2011. Model Evaluasi Pembelajaran Sejarah. Yogyakarta: Lkis

3. Amin, Jusna J.A. 2016. Mengenal Arsitektur Lansekap Nusantara. Jakarta : Pustaka Pelajar

4. Bourdillon, H. 1994. Teaching History. London. Routledge

5. Fanani ,Achmad ( Peraih Aga Khan Award Bidang Arsitektur).. 2009. Arsitektur Masjid Yogyakarta : Benteng Pustaka

6. Kasdi Aminudin. 2009. Kepurbakalaan Sunan Giri Sosok Akulturasi Kebudayaan Indonesia Asli, Hindu-Budha dan Islam Abad 15-16. Surabaya : Unessa University Press 
7. Kartodirjo, Sartono, 1993. Pemikiran dan Perkembangan Historiografi Indonesia. Jakarta: PT Gramedia

8. Koentjaraningrat.2009. Pengantar Ilmu Antropologi ( edisi Revisi). Jakarta : Rineka Cipta

9. Kochhar, S.K. 2008. Pembelajaran Sejarah. Jakarta: PT Gramedia

10. Lickona, T. 2012. Mendidik Untuk Membentuk Karakter: Bagaimana Sekolah dapat Memberikan Pendidikan tentang Sikap Hormat dan Bertanggung Jawab. Jakarta: Bumi Aksara.

11. Lombard, Dennys. 2008. Nusa Jawa : Silang Budaya Kajian Sejarah Terpadu Bagian II Jaringan Asia. Jakarta : PN PT Gramedia Pustaka

12. Munib, Achmad. 2011. Pengantar Ilmu Pendidikan. Semarang : pusat Pengembangan MKDU dan MKDK LP3 UNNES

13. Ruwana Salain, Putu.2013. Arsitektur Posmo Pada Masjid Al Hikmah Dalam serapan Arsitek Tradisional Bali. Denpasar : Udayana University Press.

14. Soekmono.1981. Pengantar Sejarah Kebudayaan Indonesia 3. Yogyakarta : PT Kanisius

15. Tirtarahardja, U. 1994. Pengantar Pendidikan . Jakarta : Dirjen Dikti Depdikbud

16. Tjandrasasmita, Uka. 2009. Arkeologi Islam Nusantara. Jakarta : PN PT Gramedia Pustaka

17. Widja I Gede. 1989. Sejarah Lokal : suatu prespektif dalam pengajaran sejarah. LPTK Depdikbud 